\title{
EKOLOGI POLITIK MASYARAKAT PESISIR CIREBON; Sketsa dari Desa Citemu Kecamatan Mundu
}

\author{
A. Syatori \\ IAIN Syekh Nurjati Cirebon
}

\begin{abstract}
Abstrak: Cirebon merupakan salah satu daerah yang terletak di pesisir pantai utara jawa, dimana sebagian masyarakatnya berprofesi sebagai nelayan. Profesi ini tentu saja bergantung pada sekali pada sumber daya alam, dalam hal ini adalah laut yang meruopakan open access. Karakteristik sumber daya seperti ini menyebabkan nelayan mesti berpindah-pindah untuk memperoleh hasil maksimal, yang dengan demikian elemen resiko menjadi sangat tinggi. Kondisi sumber daya yang beresiko tersebut menyebabkan nelayan memiliki karakter keras, tegas dan terbuka. Dan bagi nelayan, kondisi lingkungan wilayah pesisir dan laut sangat menentukan keberlanjutan kondisi sosial ekonomi dan kesejahteraan hidup mereka. Tulisan ini bertujuan untuk menggambarkan ekologi politik masyarakat Cirebon, dengan mengambil lokasi penelitian di desa Citemu kecamatan Mundu Cirebon.
\end{abstract}

Kata Kunci: Ekologi Politik, Masyarakat Pesisir

\section{A. Pendahuluan}

Secara geografis, masyarakat pesisir atau nelayan adalah masyarakat yang hidup, tumbuh dan berkembang di kawasan pesisir, yakni suatu kawasan transisi antara wilayah darat dan laut. Secara sosiologis, mereka memiliki karakteristik sosial yang berbeda dengan masyarakat lainnya, masyarakat petani, misalnya, karena perbedaan karakteristik sumberdaya yang dimiliki. Masyarakat petani menghadapi sumber daya yang terkntrol, yakni pengelolaan lahan untuk produkdi suatu komoditas dengan output yang relatif bisa diprediksi. Dengan sifat produksi yang demikian memungkinkan tetapnya lokasi produksi sehingga menyebabkan mobilitas usaha yang relatif rendah dan elemen resiko yang tidak besar. Dalam hal ini, petani ikan tergolong masyarakat petani karena kemiripan karakteristik sumber daya yang dihadapi, yaitu petani ikan (budidaya) mengetahui berapa, dimana, dan kapan ikan ditangkap sehingga pola pemanenan lebih terkntrol. Pola pemanenan yang terkntrol itu tentu disebabkan karena adanya input yang terkontrol pula. 
Karakteristik tersebut berbeda sama sekali dengan nelayan. Nelayan menghadapi sumber daya yang hingga kini masih bersifat open access. Karakteristik sumber daya seperti ini menyebabkan nelayan mesti berpindah-pindah untuk memperoleh hasil maksimal, yang dengan demikian elemen resiko menjadi sangat tinggi. Kondisi sumber daya yang beresiko tersebut menyebabkan nelayan memiliki karakter keras, tegas dan terbuka (Satria, 2009: 336). Bagi nelayan, kondisi lingkungan wilayah pesisir dan laut sangat menentukan keberlanjutan kondisi sosial ekonomi dan kesejahteraan hidup mereka.

Dalam konteks sosiologis, penduduk atau masyarakat yang menghuni kawasan pesisir, ditilik dari besaran populasi, perbedaan mata pencaharian dan sumber penghidupan dapat dikelompokkan ke dalam empat jenis satuan sosial yang kerapkali menjadi satuan administrasi pemerintahan, yaitu: pertama, desa pesisir tipe bahan makanan, yaitu desa-desa yang sebagian besar atau seluruh penduduknya bermatapencaharian sebagai petani sawah; kedua, desa pesisir tipe tanaman industri, yaitu desa-desa yang sebagian besar atau seluruh penduduknya bermatapencaharian sebagai petani tanaman industri; ketiga, desa pesisir tipe nelayan/empang/tambak, yaitu desadesa yang sebagian besar atau seluruh penduduknya bermatapencaharian sebagai nelayan, petambak, dan pembudidaya perairan; dan keempat, desa pesisir tipe niaga dan transportasi, yaitu desa-desa yang sebagian besar atau seluruh penduduknya bermatapencaharian sebagai pedagang antar pulau dan penyedia jasa transportasi antar wilayah (laut) (Hasanuddin, 1985:108).

Membicarakan masyarakat nelayan hampir pasti isu yang selalu muncul adalah masyarakat yang marjinal, miskin dan menjadi sasaran eksploitasi penguasa baik secara ekonomi maupun politik. Kemiskinan dan kesulitan-kesulitan hidup lainnya merupakan siklus peristiwa sosial ekonomi yang selalu berulang setiap tahun atau bahkan sepanjang tahun menimpa rumah tangga nelayan. Kemiskinan yang selalu menjadi trade mark bagi nelayan dalam beberapa hal dapat dibenarkan dengan beberapa fakta seperti kondisi pemukiman yang kumuh, tingkat pendapatan dan pendidikan yang rendah, rentannya mereka terhadap perubahanperubahan sosial, politik, dan ekonomi yang melanda, dan ketidakberdayaan mereka terhadap intervensi pemodal, dan penguasa yang datang. Selain itu, kemiskinan mereka juga diakibatkan oleh masalah kerusakan ekosisitem pesisir-laut yang berdampak serius terhadap menipisnya sumberdaya perikanan. Di samping persoalan lingkungan pesisir dan laut, kemiskinan 
nelayan merupakan isu besar yang terjadi karena faktor-faktor yang kompleks (Kusnadi, 2002: 4-12)

Persoalan lain yang menjadi akar kemiskinan nelayan adalah ketergantungan yang tinggi terhadap kegiatan penangkapan. Faktor-faktor ketergantungan ini sangat beragam. Akan tetapi, jika ketergantungan itu terjadi di tengah-tengah masih tersedianya pekerjaan lain di luar sektor perikanan, tentu saja hal ini sangat mengurangi daya tahan nelayan dalam menghadapi tekanan-tekanan ekonomi. Nelayan juga kurang menyadari bahwa kondisi eksistem perairan mudah berubah setiap saat, sehingga bisa berpengaruh terhadap pendapatan mereka. Selain itu, sifat sumber daya perikanan sebagai sumber daya milik umum yang bergerak dinamis dan fluktuasi musim penangkapan akan mengganggu knsistensi perolehan pendapatan nelayan. Di samping itu, rendahnya keterampilan nelayan untuk melakukan diversifikasi kegiatan penangkapan dan keterikatan yang kuat terhadap pengperasian satu jenis alat tangkap telah memberikan kntribusi terhadap timbulnya kemiskinan nelayan. Karena terikat pada satu jenis alat tangkap dan untuk menangkap satu jenis ikan tertentu maka ketika sedang tidak musim jenis ikan tersebut, nelayan tidak dapat berbuat banyak (Kusnadi, 2008: 78).

Kondisi lain yang turut berkontribusi memperburuk tingkat kesejahteraan nelayan adalah mengenai kebiasaan atau pola hidup. Tidak pantas jika kita menyebutkan nelayan pemalas, karena jika dilihat dari daur hidup nelayan yang selalu bekerja keras. Namun kendalanya adalah pola hidup konsumtif, dimana pada saat penghasilan banyak, tidak ditabung untuk persiapan paceklik, melainkan dijadikan kesempatan untuk membeli kebutuhan sekunder. Namun ketika paceklik, pada akhirnya berhutang, termasuk kepada lintah darat, yang justru semakin memperberat kondisi. Masalah lain yang tak kalah penting dalam kegiatan ekonomi nelayan, terutama terkait operasional penagkapan ikan adalah persoalan modal usaha untuk menyediakan segala kebutuhan kegiatan penagkapan ikan, seperti bahan bakar kapal, alat-alat penagkap ikan dan sebagainya.

Bagi masyarakat nelayan, khusunya nelayan kecil atau nelayan tradisional, kebutuhan akan modal usaha, yang bisa diakses atau yang bisa didayagunakan setiap saat tersebut, sangat tinggi. Kondisi ini merupakan respon atas besarnya biaya investasi di sektor perikanan tangkap, sedangkan perolehan 
pendapatan tidak pasti dan tingkat penghasilan bervariatif. Dengan kebutuhan konsumsi rumah tangga yang harus dipenuhi setiap hari, nelayan tidak memiliki tabungan dana yang mencukupi jika suatu saat harus berhadapan dengan kenyataan bahwa sarana-prasarana penangkapan yang mereka gunakan mengalami kerusakan dan membutuhkan biaya perbaikan yang cukup besar. Keterbatasan pemilikan dana kontan inilah yang kemudian mendorong nelayan terperangkap dalam jaringan hutang piutang yang kompleks, khususnya kepada para rentenir atau penyedia kredit informal.

\section{B. Diskursus Ekologi Politik}

Terma ekologi merupakan konsep yang menggambarkan hubungan antara manusia dan lingkungannya. Sebagai bidang ilmu pengetahuan, ekologi betujuan untuk memberikan ilustrasi hubungan antara manusia dan spesies lainnya. Perubahan lingkungan juga dilihat sebagai hasil hubungan antara manusia dan spesies lainnya (Forsyth, 2003). Sedangkan ekologi politik mengacu pada upaya pengkombinasian perhatian pada ekologi dan ekonomi politik secara luas yang mencakup dialektika antara masyarakat dan sumber daya, serta dialektika kelas dan kelompok sosial di dalam masyarakat itu sendiri. Ekologi politik merupakan the social and political conditions surrounding the causes, experiences, and management of environmental problem (Forsyth, 2003).

Dengan semangat konseptual tersebut, ekologi politik mengambil posisi, pertama: sebagai perhatiannya kepada 'skala', yang memungkinkan para ilmuwan untuk mengidentifikasi dan menganalisa rantai yang menghubungkan dinamika lingkungan dengan kekuatankekuatan sosial, politik, budaya dan ekonomi pada berbagai situs konseptual dan fisik, dan kedua: fokusnya yang konsekuen pada 'kuasa' dalam berbagai perwujudannya sebagai kunci pusat untuk memahami bagaimana gagasan tentang kesinambungan diciptakan dan disebarkan (Neumann 2005; Robbins 2003).

Kajian ekologi politik merupakan kelanjutan dari ekologi budaya. Jika ekologi budaya lebih memfokuskan kajian pada praktikpraktik pengelolaan sumber daya yang dibangun secara budaya dan lokal. Kajian ekologi politik memfokuskan diri lebih pada penjelasan politik terhadap degradasi dan perubahan lingkungan. Ekologi-politik merupakan bidang kajian yang mempelajari aspek-aspek sosial-politik terhadap pengelolaan lingkungan. Dalam ekologi-politik, masalah ekologi bukanlah masalah teknis, tetapi lebih merupakan akibat dari tatanan politik dan ekonomi yang ada serta proses politik dari aktor- 
aktor yang berkepentingan. Seluruh proyek dan argumen ekologis selalu simultan dan diikuti dengan proyek dan argumen ekonomi politik dan demikian pula sebaliknya. Argumen ekologis tidak pernah bisa netral secara sosial, begitu juga argumen sosial politik tidak pernah bisa netral secara ekologis.

Asumsi pokok dalam ekologi-politik bermuara pada pendirian bahwa perubahan lingkungan tidaklah bersifat netral, tetapi merupakan suatu bentuk politized environment yang banyak melibatkan aktoraktor yang berkepentingan baik pada tingkat lokal, regional, maupun global (Bryant, 2001). Aktor yang dominan umumnya adalah negara dan swasta besar. Dominasi ini menyebabkan apa yang disebut tragedy of enclosure, yakni tragedi akibat dominasi negara dan swasta yang menyebabkan akses masyarakat pada pemanfaatan dan pengelolaan makin dibatasi. Melemahnya akses ini membuat masyarakat makin marjinal. Tujuan dari ekologi-politik tidaklah hanya sebagai penjelas atas fenomena perubahan lingkungan semata, tetapi juga merupakan pijakan penting dalam formulasi kebijakan pengelolaan lingkungan.

Berangkat dari ranah studi pembangunan kritis (critical development studies), studi ekologi politik menilai bahwa keputusan pengelolaan sumber daya alam tidak bisa dipahami hanya dari sudut pandang teknis yang memprioritaskan efisiensi. Sebaliknya, 'kehijauan' dari perencanaan pembangunan akan ditemukan bukan dalam kepeduliannya terhadap ekologi atau lingkungan di dalam dirinya, tetapi dalam keprihatinannya dengan masalah kekendalian, kekuasaan, dan kedaulatan (Adams, 1990: 253). Penemuan-penemuan utama teori ekologi politik mengutarakan bahwa pola-pola pengembangan sumber daya muncul dari interaksi antara sistem alam (misalnya kualitas, kuantitas, dan lokasi air) dan sistem sosial (misalnya penyebaran kekuasaan ekonomi, sosial, dan politikdidalam suatu masyarakat).

Ada enam hal yang mesti diperhatian dalam kajian ekologi politik. Pertama, environmental problems as the phenomenological interaction of biophysical process, human needs, and wider political system; kedua, both a set theoretical propositions ang ideas on the one hand and on the other a social movement referred to as the ecology movement; ketiga, the interactive interdepedence among sphere: the individual, the community, the natural world, and the national society; keempat, a more specific analysis of Marxist debates about materialism, justice, and nature in capitalist societies, with the view to achieving a fairer distribution of rights dan recourses; kelima, inquiry into the political forces, conditions, and ramifications of environmental change; location specific aspects of ecological change; 
and the effects of environmental change on socio-economic and political relationship; dan keenam, a debates focuses on interactions between the state, nonstate actors, and the physical environment, whereas environmental politics as a debates concerns the role of the state generally.

Dalam kajian ekologi politik, terdapat beberapa pendekatan yang dapat digunakan. Pertama, pendekatan yang bertumpu pada masalah lingkungan secara spesifik, dan pijakannya adalah perspektif atau bidang kajian traditional geography, serta berkaitan dengan upaya memahami dampak manusia terhadap lingkungan fisik. Kedua, pendekatan yang bertumpu pada konsep terkait dengan pertanyaan ekologi politik, yakni mengeksplorasi bagaimana konsep-konsep tersebut dikonstruksi. Analisis wacana tampak dominan dalam pendekatan ini, seperti analisis terhadap wacana yang mendominasi sekitar konsep pembangunan yang berkelanjutan dalam rangka memperjelas asumsi-asumsi dasar tentang masyarakat dan alam, serta ekonomi-politik yang membuat asumsi itu ada. Ketiga, pendekatan yang melihat kaitan politik dengan masalah ekologis dalam konteks wilayah geografis tertentu, seperti kajian masalah lingkunagn di asia, Afrika dan sebagainya. Keempat, pendekatan yang mengeksplorasi pertanyaan-pertanyaan ekologi politik terkait dengan karakteristik sosial-ekonomi, seperti kelas, gender dan etnik. Kelima, pendekatan yang menekankan kebutuhan untuk fokus pada kepentingan, karakteristik dan tindakan dari para aktor dalam memahami konflik politik dan ekologi (Bryant and Bailey, 2000).

Pada aras yang lain, dalam diskursus ekologi politik terdapat beberapa tesis besar yang saling terkait satu sama lain. Pertama, degradasi dan marjinalisasi; isunya perubahan lingkungan yang terjadi akibat over-eksploitasi yang kemudian menyebabkan kemiskinan. Kedua, konflik lingkungan; isunya akses lingkungan, yaitu adanya kelangkaan sumber daya akibat pemanfaatan oleh negara, swasta, dan elite sosial yang kemudian mempercepat konflik antar kelompok. Ketiga, konservasi dan kontrol; isunya kegagalan konservasi yang disebabkan oleh tercerabutnya peran masyarakat lokal dalam pengelolaan sumber daya, serta diabaikannya mata pencaharian dan organisasi sosial-ekonomi mereka hanya karena untuk melindungi lingkungan. Keempat, identitas lingkungan dan gerakan sosial; perjuangan sosial plitik biasanya terkait dengan upaya mempertahankan mata pencaharian dan perlindungan lingkungan (Robbins, 2004).

Sementara itu, antara ekologi politik dan politik lingkungan (environmental politics) yang seringkali dipersamakan sesungguhnya 
memiliki perbedaan yang cukup mendasar. Environmental politics merupakan bidang kajian dalam ilmu politik terhadap masalahmasalah lingkungan, yakni meneliti dampak isu lingkungan terhadap terhadap proses politik formal serta peran negara dalam pengelolaan lingkungan. Environmental politics mempelajari ekologi dengan mendasarkan pada pertanyaan-pertanyaan politik tradisional. Sehingga seringkali pendekatan ini bias hanya kepada aktor-aktor atau institusiinstitusi besar (global). Untuk itu, perhatian utama kajian ini adalah only cnsiders the environment in $s$ far as it intrudes $n$ the frmal plitical process. (Bryant and Bailey, 2001). Oleh karena itu, environmental politics dianggap berperspektif technocentric daripada ecocentric sehingga kaitannya dengan ekologi politik tidaklah terlalu kuat.

Environmental politics, menurut Walters (2004:1) mempelajari bagaimana manusia mengorganisasikan dirinya dan struktur perilakunya untuk melindungi kepentingan mereka di dalam lingkungan. Ia mempelajari dinamika gerakan-gerakan sosial, kelembagaan dan pembuatan kebijakan pemerintah serta interaksi yang terjadi di dalamnya. Berbeda dengan Environmental politics, ekologi politik lebih menekankan kajiannya pada kondisi dan konsekuensi-konsekuensi politik dari perubahan lingkungan yang terjadi. Blaikie dan Brookfield (1987) mendefinisikan ekologi politik ini sebagai kombinasi perhatian dari ekologi dan ekonomi politik dalam arti luas, yakni dialektika antara masyarakat dan sumber daya berbasis tanah dan termasuk juga dialektika antar kelas dan kelompok di dalam masyarakat itu sendiri (Walker, 2005:74).

\section{Kebijakan Ekologis Masyarakat Pesisir}

Banyak program telah dilakukan pemerintah untuk mengatasi persoalan kemiskinan dan kesejahteraan hidup nelayan. Program yang bersifat umum antara lain Program Inpres Desa Tertinggal (IDT), Program Keluarga Sejahtera, Program Pembangunan Prasarana Pendukung Desa Tertinggal (P3DT), Program Pengembangan Kecamatan (PPK), dan Program Jaring Pengaman Sosial (JPS). Sedangkan program yang secara khusus ditujukan untuk kelompok sasaran masyarakat nelayan antara lain program Pemberdayaan Masyarakat Pesisir (PEMP) dan Program Pengembangan Usaha Perikanan Tangkap Skala Kecil (PUPTSK).

Namun, secara umum program-program tersebut tidak membuat nasib nelayan menjadi lebih baik daripada sebelumnya. Salah satu penyebab kurang berhasilnya program-program pemerintah dalam menanggulangi kemiskinan nelayan adalah formulasi kebijakan yang bersifat top down. Formula yang diberikan cenderung seragam 
padahal masalah yang dihadapi nelayan sangat beragam dan seringkali sangat spesifik lokal. Di samping itu, upaya penanggulangan kemiskinan nelayan seringkali sangat bersifat teknis perikanan, yakni bagaimana upaya meningkatkan produksi hasil tangkapan, sementara kemiskinan harus dipandang secara holistik karena permasalahan yang dihadapi sesungguhnya jauh lebih kompleks dari itu.

Oleh karena itu, perlu sekali diterbitkan sebuah kebijakan sosial yang berisikan keterpaduan penanganan kemiskinan nelayan sebagaimana yang mereka butuhkan, kebijakan tersebut juga harus didukung oleh kebijakan yang diterbitkan oleh pemerintah kabupaten atau kota dimana terdapat masyarakat miskin khususnya masyarakat yang berprofesi sebagai nelayan. Tujuannya adalah untuk menghilangkan keegoan dari masing-masing pemangku kepentingan. Keterpaduan tersebut adalah sebagai berikut : pertama, keterpaduan sektor dalam tanggung jawab dan kebijakan. Keputusan penanganan kemiskinan nelayan harus diambil melalui proses koordinasi diinternal pemerintah, yang perlu digaris bawahi adalah kemiskinan nelayan tidak akan mampu ditangani secara kelembagaan oleh sektor kelautan dan perikanan, melainkan seluruh pihak terkait.

Kedua, keterpaduan keahlian dan pengetahuan, untuk merumuskan berbagai kebijakan, strategi, dan program harus didukung berbagai disiplin ilmu pengetahuan dan keahlian, tujuannya adalah agar perencanaan yang disusun betul-betul sesuai dengan tuntutan kebutuhan masyarakat nelayan. Ketiga, keterpaduan masalah dan pemecahan masalah sangat diperlukan untuk mengetahui akar permasalahan yang sesungguhnya, sehingga kebijakan yang dibuat bersifat komprehensif, dan tidak parsial. Keempat, keterpaduan lokasi, memudahkan dalam melakukan pendampingan, penyuluhan dan pelayanan (lintas sektor), sehingga program tersebut dapat dilakukan secara efektif dan efesien.

Berbagai kebijakan yang dilakukan belum mampu mengangkat kerangkeng kemiskinan para nelayan. Kebijakan pembangunan kelautan selama ini, cenderung lebih mengarah kepada kebijakan "produktivitas" dengan memaksimalkan hasil eksploitasi sumber daya laut tanpa ada kebijakan memadai yang mengendalikannya. Akibat dari kebijakan tersebut telah mengakibatkan beberapa kecenderungan yang tidak menguntungkan dalam aspek kehidupan, seperti:

- Aspek ekologi, overfishing penggunaan sarana dan prasarana penangkapan ikan telah cenderung merusak ekologi laut dan pantai (trawl, bom, potas, pukat harimau, dan sebagainya). Akibat dari ini adalah menyempitnya wilayah dan sumber daya tangkapan, sehingga sering menimbulkan konflik secara terbuka baik bersifat 
vertikal dan horisontal (antara sesama nelayan, nelayan dengan masyarakat sekitar dan antara nelayan dengan pemerintah).

- Aspek sosial ekonomi, akibat kesenjangan penggunaan teknologi antara pengusaha besar dan nelayan tradisional telah menimbulkan kesenjangan dan kemiskinan bagi nelayan tradisional. Akibat dari kesenjangan tersebut menyebabkan sebagian besar nelayan tradisional mengubah profesinya menjadi buruh nelayan pada pengusaha perikanan besar.

- Aspek sosio kultural, dengan adanya kesenjangan dan kemiskinan tersebut menyebabkan ketergantungan antara masyarakat nelayan kecil/tradisional terhadap pemodal besar/modern, antara nelayan dan pedagang, antara pherphery terdapat center, antara masyarakat dengan pemerintah. Hal ini menimbulkan penguatan terhadap adanya komunitas juragan dan buruh nelayan.

Masalah kemiskinan merupakan hal yang sangatlah kompleks yang disebabkan oleh berbagai faktor, sebab-sebab kompleks kemiskinan nelayan dapat di katagorikan ke dalam 2 hal yaitu:

a. Faktor internal. Sebab internal dari kemiskinan nelayan berkaitan dengan sumber daya manusianya dalam hal ini nelayan dan aktivitas kerja mereka, hal ini mencakup:

- Terbatasnya kualitas sumber daya manusia nelayannya

- Keterbatasan kemampuan modal usaha dan teknologi penangkapan

- Hubungan kerja (pemilik perahu, nelayan buruh) dalam organisasi penangkapan yang dianggap merugikan nelayan buruh

- Kesulitan melakuan diversifikasi usaha penangkapan

- Ketergantungan tinggi terhadap okupasi melaut

- Gaya hidup yang dipandang boros sehingga kurang berorientasi kemasa depan.

b. Faktor eksternal. Sedangkan sifat kemiskinan eksternal berkaitan dengan aktivitas kerja nelayan yaitu :

- Kebijakan pembangunan perikanan yang lebih berorientasi pada produktivitas untuk menunjang pertumbuhan ekonomi nasional dan persial

- Sistem pemasaran hasil perikanan yang lebih menguntungkan pedagang perantara

- Kerusakan ekologi pesisir dan laut karena pencemaran dari daerah daratan

- Penggunaan peralatan tangkap yang tidak ramah ingkungan 
- Penerapan hukum yang lmah terhadap perusakan lingkungan

- Terbatasnya teknologi pengolahan hasil tangkapan pascapanen

- Terbatasnya peluang-peluang kerja disektor non pendidikan yang tersedia didesa-desa

- Kondisi alam dan fluktuasai musim yang tidak memungkinkan nelayan melaut sepanjang tahun

- Isilasi geografis desa nelayan yang menggunakan mobilitas barang, modal dan manusia.

Kedua sebab tersebut saling berinteraksi dan semakin menambah penderitan dan kemiskinan masyarakat nelayan. Problem kemiskinan masyarakat nelayan mulai muncul ke permukaan setelah satu dekade dilaksanakannya kebijakan nasional tentang motorisasi perahu dan modernisasi peralatan tangkap pada awal tahun 1970-an. Kebijakan ini dikenal dengan istilah revolusi biru (blue revolution). Proyek besar ini berimplikasi pada keserakahan sosial atas sumber daya perikanan yang mendorong setiap individu untuk berkuasa penuh terhadap sumber daya tersebut. Keserakahan ini akan berakibat pada kelangkaan sumber daya perikanan. Kompetisi yang semakin tinggi dan kesenjangan akses dan pendapatan yang berimplikasi pada timbulnya kesenjangan sosial ekonomi antar pengguna sumber daya perikanan

\section{Konteks Sosial Masyarakat}

Secara geografis, desa Citemu kecamatan Mundu kabupaten Cirebon terletak di pinggir pantai dengan wilayah yang terbagi menjadi dua bagian, daerah yang terletak di pinggir pantai dengan kisaran luas wilayahnya $80 \%$ berada di wilayah pantai dan sisanya, $20 \%$ terletak di seberang jalan raya merupakan kawasan persawahan/pertanian. Melihat kondisi geografis ini dan karakteristik masyarakat desa pada umumnya, dimana mereka selalu memanfaatkan sumber daya alam yang ada dilingkungan tempat tinggal sebagai mata pencahariannya, maka mata pencaharian utama masyarakat desa Citemu adalah nelayan.

Dalam melakukan aktifitas 'melaut', nelayan desa Citemu menerapkan dua bentuk mekanisme berlayar, Harian dan Babang. Proses berlayar Harian dilakukan dengan mekanisme berlayar setiap hari pulang pergi dari darat ke laut dan kembali ke darat dengan waktu pemberangkatan mulai pukul $02.00 \mathrm{WIB}$ dini hari hingga pukul 10.00 WIB. Proses berlayar Babang merupakan proses pelayaran ke laut lepas dengan waktu yang relatif lama dengan kisaran waktu antara 
empat hingga lima hari. Proses berlayar Harian merupakan proses 'melaut' yang secara umum dilakukan oleh para nelayan. Sedangkan proses berlayar Babang hanya dilakukan oleh nelayan yang memiliki modal yang besar yang disebut dengan Juragan. Dalam melakukan prses ini, Juragan membutuhkan bawahan atau pembantu yang akan membantunya selama proses berlayar tersebut yang disebut dengan nelayan biasa atau Bidak.

Juragan merupakan sebutan bagi nelayan yang memiliki modal besar dengan perahu yang besar dan peralatan berlayar yang lengkap untuk menangkap hasil laut yang lebih banyak dibading dengan nelayan biasa. Sedangkan Bidak adalah nelayan biasa yang hanya mempunyai perahu kecil atau tidak mempunyai perahu sama sekali dan hanya mempunyai peralatan berlayar yang terbatas. Untuk keperluan aktifitas melaut, bidak yang tidak memiliki perahu harus menumpang kepada perahu Juragan dan membayar sewa perahu yang dianggap sebagai pembayaran bahan bakar solar yang digunakan. Besarnya ongkos yang dibayarkan oleh Bidak kepada Juragan tergantung pada banyaknya hasil tangkapan yang didapatkan olehnya.

Dalam tatanan perekonomiannya yang sarat dengan ketergantungan terhadap sumberdaya alam yang ada, tingkat kehidupan sosial masyarakat desa Citemu berbeda dengan desa lain yang memiliki sumberdaya alam yang berbeda. Masyarakat desa Citemu yang mayoritas berprofesi sebagai nelayan menjadikan profesi tersebut sebagai profesi yang dapat diwariskan turun temurun, sehingga kehidupan sosial yang dijalankan oleh masyarakat selalu mengajarkan anak-anaknya untuk bergulat dengan keadaan alam dengan cara ikut serta melaut sehingga pada akhirnya ia tumbuh dan menjadi nelayan seperti apa yang telah diajarkan oleh orang tuanya. Alih-alih membantu orang tua dan kehidupan ekonomi orang tua, hak anak untuk mendapatkan pendidikan yang layak mejadi terampas. Mereka lebih senang membantu orang tuanya melaut dari pada meneruskan pendidikan dan bermain layaknya anak-anak pada umumnya. Sehingga jenjang pendidikan mereka sangat minim.

Mereka mengaku, sebagai nelayan tradisional, memang untuk memenuhi kebutuhan konsumsi sehari-hari sampai saat ini relatif tidak menjadi masalah, meski mungkin dalam ukuran yang sangat sederhana. Jelas capaian kebutuhan itu, sebatas memenuhi makan yang amat sederhana sebab mereka mengabaikan untuk memenuhi kebutuhan dasar lain di luar kebutuhan pangan. Seperti halnya, untuk memenuhi kebutuhan pendidikan anak, hampir sebagian besar nelayan pesisir menyatakan tidak mampu. Hal yang sama juga berlaku ketika mereka harus memenuhi kebutuhan kesehatan dan biaya sosial 
lingkungan. Mereka menyatakan tidak mampu ketika ada salah satu anggota keluarganya yang jatuh sakit. Dengan besar penghasilan yang sangat minimal dan pas-pasan untuk makan sehari-hari, memang berat jika keluarga nelayan tradisional yang miskin itu harus mengeluarkan biaya ekstra berobat ke dokter atau membeli obat di apotik yang menurut ukuran mereka relatif mahal.

Hal demikian tidak hanya berlaku bagi anak laki-laki, anak perempuan nelayan juga turut merasakan hal yang sama. Proses produksi rajungan menjadi daging adalah salah satu jenis pekerjaan yang padat karya karena dikerjakan secara manual oleh tangan-tangan keratif yang terampil dan cekatan memisahkan antara daging dan cangkang rajungan. Mereka yang menggeluti usaha demikian adalah mayoritas kaum perempuan. Sebagian besar di antara mereka adalah anak yang berusia belia dan remaja. Pekerjaan demikian dilakukan pada saat jam pelajaran di sekolah dimulai sehingga remaja-remaja belia ini meninggalkan bangku sekolahnya demi mendapatkan rupiah dengan dalih membatu orang tuanya. Sehingga banyak di antara mereka yang tidak dapat menuntaskan jenjang pendidikan.

Di kalangan keluarga nelayan tradisional, mempekerjakan anak-anak untuk ikut membantu orang tua mencari nafkah dalam usia dini adalah hal yang biasa, sehingga anak-anak mereka pun rata-rata tidak sempat menyelesaikan pendidikan hingga jenjang yang tertinggi di desanya. Berbeda dengan juragan kapal atau nelayan modern yang rata-rata hidup berkecukupan, kondisi ekonomi keluarga nelayan tradisional seringkali hidup serba pas-pasan, atau relatif kekurangan dan bahkan sangat kekurangan. Dengan kondisi musim ikan yang hanya sekitar tiga bulan dalam setahun, memang sulit berharap keluarga nelayan tradisional bisa memperoleh penghasilan yang memadai, apalagi penghasilan itu untuk kepentingan menabung.

Sementara itu, mobilitas vertikal masyarakat nelayan Citemu dapat terjadi berkat dukungan para isteri mereka yang memiliki kecakapan tertentu dalam mengolah hasil laut dan membuka peluang usaha non-nelayan, terutama perdagangan. Keterlibatan isteri dalam kegiatan perdagangan sangat terbuka lebar karena sistem pembagian kerja secara seksual memungkinnya dan sesuai dengan situasi geososial masyarakat nelayan. Dalam sistem pembagian kerja ini, nelayan bertanggungjawab terhadap urusan menangkap ikan/rajungan (ranah laut), sedangkan kaum perempuan bertanggungjawab terhadap urusan domestik dan publik (ranah darat). Sistem pembagian kerja ini memberikan tempat terhormat bagi isteri/perempuan nelayan dalam keluarga dan kehidupan masyarakat. 
Sistem pembagian kerja diatas, yang telah memberikan tempat layak bagi kaum perempuan untuk mengatasi persoalan kehidupan di ranah darat, merupakan 'katup pengaman' untuk mengantisipasi pranata-pranata sosial ekonomi yang dianggap pihak lain merugikan kehidupan nelayan. Kaum perempuan terlibat penuh dalam kegiatan pranata-pranata sosial ekonomi yang mereka bentuk seperti arisan, kegiatan pengajian berdimensi kepentingan ekonomi, dan simpan pinjam serta jaringan sosial yang bisa mereka manfaatkan untuk menunjang kelangsungan hidup keluarga. Kaum perempuan tidak sekedar membantu suami mencari nafkah, tetapi mereka sangat menentukan kelangsungan hidup keluarga. Dari sisi tanggungjawab sosial ekonomi keluarga ini, suami dan isteri nelayan berposisi sejajar (komplementer). Kaum perempuan dan pranata-pranata sosial budaya yang ada merupakan potensi pembangunan masyarakat nelayan yang bisa dieksplorasi untuk mengatasi kemiskinan dan kesulitan ekonomi lainnya.

Strata pendidikan yang rendah menjadikan mereka hanya berkutat pada satu hal, menjadi nelayan, mengolah hasil tangkapan dan lain sebagainya yang berkaitan dengan kehidupan nelayan. Kepentingan administrasi kependudukan bagi mereka bukanlah hal yang harus diperhatikan sehingga mereka merasa tidak membutuhkan Kartu Tanda Penduduk (KTP). Bekerja di laut dan menghabiskan harihari di tengah laut lepas menjadikan mereka merasa tidak membutuhkannya, sehingga mereka acuh terhadapnya. Sementara kemajuan zaman menuntut untuk melakukan sesuatu yang jauh dari pemahaman sempit mereka. Kartu Tanda Penduduk (KTP) menjadi hal yang wajib bagi mereka yang tidak hanya sekedar menjadi tanda identitas bagi mereka, tetapi juga sebagai salah satu prosedur administrasi yang sering dibutuhkan untuk kepentingan sosial dan lainnya.

Minimnya pendidikan juga tidak hanya berimbas pada tingkat perekonomian masyarakat melainkan mengakibatkan pada minimnya pengetahuan serta kesadaran terhadap kondisi mereka sendiri. Hal demikian terlihat pada kebiasaan mereka yang tidak sadar akan kebersihan lingkungan, sehingga mereka membuang sampah sembarangan serta acuh terhadap kebersihan. Padahal kebersihan lingkungan merekapun salah satu aspek utama bagi kehidupan nelayan yang menggantungkan hidupnya terhadap sumber daya alam.

Persoalan dan arti penting tingkat pendidikan ini biasanya baru muncul tatkala seorang nelayan ingin berpindah pekerjaan lain yang lebih menjanjikan. Dengan pendidikan yang rendah, jelas kondisi itu akan mempersulit nelayan tradisional memilih atau 
memperoleh pekerjaan lain, selain menjadi nelayan. Nelayan tradisional umumnya mempunyai ciri yang sama, yaitu cenderung kurang dalam capaian pendidikan formal. Misalnya, dari hasil penelitian Kusnadi, 2002), dari 50 nelayan tradisional yang diteliti, sebagian besar nelayan tradisional hanya berpendidikan SD (55\%), dan bahkan 35\% responden mengaku sama sekali tidak pernah mengenal bangku sekolah. Untuk bekal bekerja mencari ikan di laut, latar belakang pendidikan seseorang memang tidak penting. Artinya, karena pekerjaan sebagai nelayan sedikit banyak merupakan pekerjaan kasar yang lebih banyak mengandalkan otot dan pengalaman, maka setinggi apa pun tingkat pendidikan nelayan itu tidaklah akan mempengaruhi kecakapan mereka melaut

Minimnya pengetahuan juga mengakibatkan mereka menjadi terbelakang dengan dunia luar yang bersifat formal sehingga tingkat mobilisasi mereka hanya berkutat pada sektor nelayan yang dilakukan melalui proses perantauan. Perantauan ini dilakukan apabila kondisi tangkapan di laut tempat tinggal di mana mereka berada semakin menurun sehingga mereka pergi ke daerah lain untuk mencari tangkapan yang kebih banyak.

Menjalani kehidupan sebagai masyarakat pesisir warga desa Citemu kental akan adat yang rutin dilaksanakan pada setiap tahunnya. Diantara adat tersebut adalah upacara adat nadranan, yaitu upacara adat yang dilakukan rutin tiap satu tahun sekali yang difungsikan sebagai bentuk syukur kepada Tuhan melalui proses pelarungan sesaji berupa kepala kerbau ke tengah laut. Adat tersebut merupakan salah satu kepercayaan masyarakat nelayan yang mengakar yang mana mereka mempercayai bahwa dengan adat tersebut akan mendapatkan keselamatan dan hasil yang melimpah. Sehingga adat tersebut masih terus dijalankan dan dilakukan bagi masyarakat nelayan.

Kepercayaan dan anggapan sakral pada adat nadranan ini menjadikan ketakukan bagi masyarakat desa Citemu untuk tidak menjalankan proses ritual upacara adat nadranan tersebut pasalnya kepercayaan akan kemaslahatan dan keselamatan yang mereka dapatkan adalah melalui upacara adat nadranan tersebut. Upacara adat nadranan tersebut dilakukan setiap satu tahun sekali khususnya pada bulan Juni pada kalender masehi dan menggunakan kepala kerbau sebagai sesaji utama yang wajib di larungkan ketengah lautan. Kepala kerbau dianggap memiliki makna tersendiri bagi masyarakat desa Citemu yang diinginkan oleh dewa laut. Unsur adat yang demikian menjadi kepercayaan mendasar bagi masyarakat yang tidak dapat diganggu gugat, namun seirinng dengan berkembangnya sistem penyebaran ajaran dan kegiatan yang lebih islami oleh beberapa tokoh 
masyarakat desa Citemu terjadi sedikit perubahan terhadap ritual-ritual yang dilakukan pada upacara adat tersebut. Seperti penerapan upacara dengan cara yang lebih islami dengan diselipkan upacara tahlil sebagai bentuk syukur.

Dalam hal sistem kekuasaan, desa Citemu sama seperti desa lain pada umumnya, memiliki pemerintahan dan wilayah kekuasaan, memiliki lembaga dan kelembagaan serta sistem pemerintahan yang dipimpin oleh kepala desa pada umumnya. Struktur pemerintahan pada desa Citemu juga masih relatif sama seperti layaknya desa pada umumnya. Hanya saja sistem demokrasi yang dianut oleh masyarakat desa Citemu sedikit berbeda dengan pesta demokrasi pada umumnya. Masyarakat desa Citemu tidak maerasa antusias untuk memeriahkan pesta demokrasi pemilihan kepala desanya sehingga pemilihan tersebut hanya sebatas formalitas.

Dalam struktur lembaga dan kelembagaan desa Citemu memang relatif sama dengan desa pada umumnya, namun perbedaan sistem yang dijalankan oleh pemerintahan desa Citemu dengan desa lainnya jauh berbeda. Seperti proses pengambilan kebijakan yang tidak selalu berpihak kepada masyarakat. Pada sistem pengambilan kebijakannya, pemerintah desa Citemu tidak melibatkan masyarakat untuk turut andil menyumbangkan aspirasinya dalam menentukan kebijakan untuk kemaslahatan bersama. Hal ini tercermin dari berbagai kebijakan yang tidak dapat dirasakan adil oleh masyarakat. Bantuan pemerintah terhadap masyarakat nelayan yang digunakan untuk kepentingan nelayan menjadi tidak berarti dan tidak bermanfaat bagi kepentingan masyarakat. Pasalnya, realisasi program bantuan yang diluncurkan oleh pemerintah untuk kelompok nelayan tidak berjalan pada koridor yang sesungguhnya yang menyentuh pada kepentingan dan kebutuhan masyarakat.

\section{E. Sistem Ekonomi Masyarakat Citemu}

Dalam pengelolaan hasil yang didapatkan dari aktifitas melaut, nelayan menggunakan sistem produksi dan distribusi yang telah berjalan hingga saat ini. Dengan tatanan sistem sebagai berikut: nelayan memproduksi hasil tangkapan berupa rajungan yang kemudian didistribusikan kepada Bakul (tengkulak) dengan harga yang telah ditentukan oleh Bakul. Setelah itu, proses distribusi bergulir pada Bos yaitu tengkulak besar yang akan mendistribusikan hasil tangkapan nelayan kepada agen besar seperti PT atau perusahaan yang mengolahnya dan akhirnya sampai kepada tangan konsumen hingga ekspor ke luar negeri. Berikut skema proses pendistribusian tersebut: 


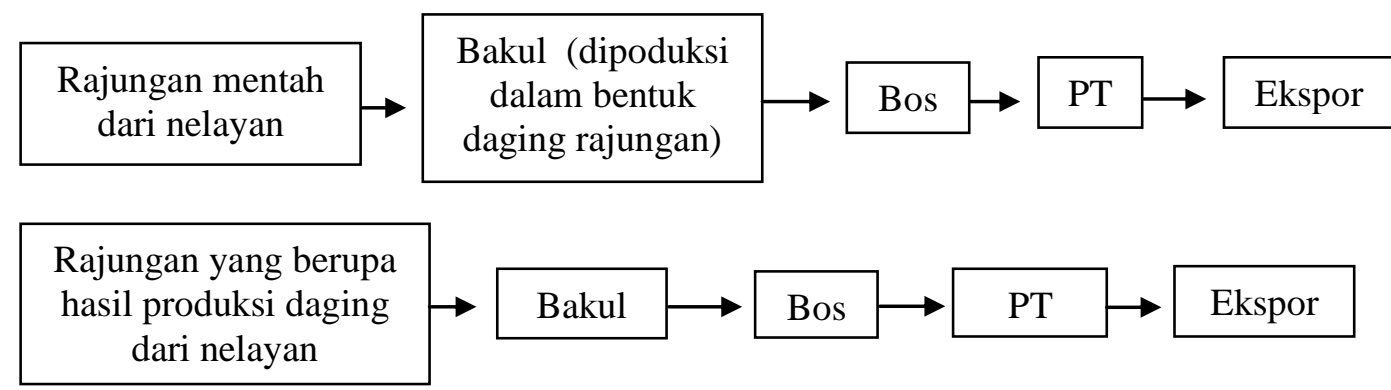

Proses pendistribusian yang telah disebutkan dalam skema tersebut mengandung berbagai sistem yang terkait di dalamnya. Sistem yang terdapat pada proses pendistribusian hasil tangkapan nelayan pada skema terdapat sistem distribusi yang terkait di antaranya adalah mengenai penetapan harga yang ditentukan oleh Bakul, yakni dengan kisaran harga mencapai Rp 40.000,-/kg. Sementara pada sistem distribusi kedua sistem harga yang berlaku adalah berkisar sampai Rp $110.000,-/ \mathrm{kg}$. Sistem penentuan harga ini berada di tangan Bakul sebagai agen utama yang menadah hasil tangkapan nelayan dengan kebijakan yang berbeda antara nelayan yang satu dengan yang lainnya. Sistem kebijakan harga ini berbeda mana kala nelayan memiliki persangkutan hutang dengan Bakul berupa modal barang maupun modal uang untuk memenuhi kebutuhan modal alat yang digunakan untuk mendapatkan hasil tangkapan. Sistem harga yang diberlakukan kepada nelayan oleh Bakul apabila nelayan memiliki hutang adalah dengan cara pengurangan harga rajungan dari harga normal yang tidak dianggap sebagai pencicilan atas hutang modal yang ditanggung oleh nelayan.

Pada proses distribusi rajungan skema pertama, sistem harga yang diberlakukan oleh Bakul kepada nelayan yang berhutang adalah berkisar hingga Rp 35.000,-/kg. Sementara pada skema kedua sistem harga yang diberlakukan bagi nelayan yang memiliki hutang kepada Bakul berkisar hingga Rp 105.000,-/kg. Sistem pengurangan harga bagi nelayan yang memiliki hutang tersebut tidak dianggap sebagai angsuran atas hutang nelayan kepada Bakul sehingga jumlah hutang nelayan tetap utuh dan tetap harus membayar dengan jumlah yang telah dipinjam oleh mereka.

Sistem penetapan harga tersebut tidak berlaku bagi para Bakul terhadap Bos. Karena posisi Bakul hanyalah sebagai penyambung tangan antara nelayan dengan Bos, maka sistem harga yang berlaku bagi Bakul kepada bos dapat ditentukan oleh Bakul itu sendiri sehingga Bos tidak memiliki wewenang untuk menentukan harga. Hanya saja proses tawar menawar menjadi hal yang lazim diantara keduanya, namun Bakul selalu mendapatkan hasil yang lebih besar 
dari pada nelayan yang telah bersusah payah mencari tangkapan di tengah laut lepas. Kebijakan harga dari Bos kepada Bakul akan sama seperti nelayan kepada Bakul, mana kala Bakul memiliki hutang kepada Bos. Mekanisme dan sistem pendistribusian ini berjalan secara ketat sehingga tidak ada celah bagi nelayan untuk berusaha mencari alternatif pamasaran baru yang lebih berpihak kepadaanya. Pasalnya pemberlakuan sistem hutang modal menjadikan nelayan terikat erat kepada para Bakul untuk selalu menyetorkan hasil tangkapan kepada Bakul yang bersangkutan.

Ada beberapa tahap yang dilakukan oleh nelayan dalam memproduksi hasil tangkapannya. Pertama, nelayan menghasilkan tangkapan berupa rajungan dengan cara melaut ke laut lepas untuk mencari tangkapan yang diinginkan seperti rajungan. Dalam proses pencarian rajungan, nelayan menggunakan perahu sebagai alat transportasi dan berbagai alat tangkap berupa jaring kejer, bubu, arad, trol, garok, dan kantong untuk menangkap varietas laut seperti rajungan. Kedua, setelah hasil ini terkumpul baru kemudian nelayan sampai tahap berikutnya yaitu tahap kedua yang mana merupakan proses produksi rajungan. Hasil tangkapan yang telah didapatkan oleh nelayan dapat dengan serta merta didistribusikan kepada para Bakul dengan kondisi mentah, yang mana dalam kondisi demikian proses pemroduksian hasil tangkapan nelayan akan dilakukan oleh tangan Bakul yang bersangkutan. Namun dalam tahap pemproduksian hasil tangkapan nelayan dewasa ini dilakukan oleh para nelayan sendiri, seiring dengan meningkatnya permintaan konsumen akan daging rajungan sehingga Bakul lebih memilih untuk menadah hasil produk yang dihasilkan oleh nelayan dalam bentuk daging. Sehingga nelayan mengggunakan kesempatan demikian untuk menghasilkan produknya sendiri yakni dengan mengolah hasil tangkapannya sendiri dan memasarkannya kepada Bakul dalam bentuk produk yang telah jadi.

\section{F. Petty Bourgeois dan Petty Capitalism}

Dalam sistem perekonomian masyarakat Citemu, keberadaan Bakul atau tengkulak bagai pisau bermata dua, berperan positif dan negatif. Disatu sisi, mereka layaknya dewa penolong bagi nelayan yang sedang mengalamai pailit, karena melalui tangan mereka ini nelayan dapat terus melakukan pekerjaan melautnya, dengan bantuan modal yang dipinjamkan. Mereka juga sangat membantu dalam hal pendistribusian hasil tangkapan. Namun di sisi yang lain bagaikan 'jeruji penjara' yang mengharuskan nelayan mendekam pada suatu keadaan dan tidak bisa berbuat apa-apa, patuh terhadap segala aturan yang harus mereka jalani. 
Diantara aturan tersebut adalah nelayan harus memberikan hasil tangkapannya kepada Bakul yang telah memberi bantuan modal kepadanya dan menerima penetapan harga yang ditetapkan oleh Bakul tersebut. Harga tangkapan yang dihasilkan oleh nelayan dengan menyandang predikat sebagai nelayan yang memiliki hutang modal kepada Bakul relatif rendah dari pada nelayan yang tidak mempunyai hutang. Harga yang rendah untuk nelayan yang mempunyai persangkutan hutang tidak dianggap sebagai bentuk pembayaran atas hutang yang mereka pinjam kepada Bakul.

Bakul menggunakan uang atau modal sebagai senjata utamanya dalam menjerat para nelayan, semakin banyak modal yang dihutangkan kepada nelayan semakin banyak langganan nelayan bagi Bakul yang akan menyetorkan hasil tangkapan lautnya kepada mereka. Sehingga persaingan yang terjadi antar Bakul adalah pemberian hutang modal terhadap nelayan serta permainan harga oleh mereka untuk menarik minat para nelayan agar memberikan hasil tangkapannya kepada mereka. Adakalanya serang Bakul akan menaikkan harga dengan cara menaikkan selisih harga dari harga yang diberlakukan oleh semua bakul. Hal ini dilakukan terutama dengan tujuan menarik minat sebanyak-banyaknya nelayan agar tertarik untuk memberikan hasil tangkapan mereka kepadanya. Sehingga pada akhirnya muncullah persaingan antar bakul.

Persaingan di antara kalangan 'pemilik modal' ini tidak akan berakhir dalam perang meja hijau. Mereka cukup saling berunding untuk membicarakan kesepakatan harga. Perundingan pun terjadi mana kala sudah ada nelayan yang mengeluhkan harga yang tidak sama antara Bakul yang menjadi langganannya dengan Bakul lain yang merasa dirugikan oleh kenaikkan harga. Ia pun akan melakukan konferensi secara tertutup dengan Bakul yang telah menaikkan harga. Pasalnya nelayan yang mengeluhkan harga kepada Bakul langgananya tersebut akan meminta kenaikan harga yang sama dengan Bakul yang lain yang telah lebih dulu menaikkan harga. Dari sinilah konferensi dan asosiasi harga antar Bakul dilakukan. Walaupun tidak dilakukan secara resmi, namun asosiasi tersebut tetap ada dan berlangsung apabila ada Bakul yang merasa dirugikan sehingga dari konferensi tersebut dihasilkan kesepakatan harga yang akhirnya sesuai dan sama rata.

Untuk menjadi seorang Bakul di antara kerumunan nelayan tidak harus berpendidikan dan berilmu tinggi. Cukup hanya dengan mengetahui sistem perbakulan dan yang paling utama memiliki modal untuk membooking para nelayan agar mau menjadi langganan yang menyetorkan hasil tangkapannya kapada mereka. Sehingga banyak 
para Bakul yang memulai profesi bakulnya dari level yang sangat kecil serta berlatar belakang penduduk setempat yang sudah cukup hafal dengan sistem perekonomian nelayan dan perbakulan. Dengan hanya mengandalkan tangkapan dari beberapa orang nelayan yang pada dasarnya merupakan kerabatnya sendiri, setelah berjalan lama banyak dari para bakul kecil yang akhirnya menjadi bakul yang besar, dengan adanya suntikan modal dari para agen besar atau yang disebut dengan bos.

Penyuntikan modal juga dilakukan oleh para bos atau agen besar untuk mendapatkan langganan bakul agar menyetorkan hasil pengumpulan produksi dari nelayan. Tentu saja adanya sistem suntikan modal terhadap bakul juga mengakibatkan hukum yang berlaku sama dengan nelayan. Yaitu bakul harus terikat dan memberikan hasil pengumpulan tangkapan nelayan keada bos yang telah memberi bantauan modal kepada bakul tersebut. Walaupun harga yang diberikan kepada bakul relatif lebih tinggi dari pada yang ditetapkan bakul kepada nelayan yang merupakan keuntungan bagi para bakul tersebut.

Sistem demikian tidak berlaku bagi para bakul yang tidak memiliki hutang kepada bos. Para bakul yang memulai usahanya sendiri dengan predikat tidak memiliki hutang terhadap bos atau agen besar bebas menjual kepada agen besar manapun, namun hal demikian tidak senada dengan sistem yang berlaku bagi kalangan nelayan. Kalangan nelayan yang tidak memiliki hutang dengan bakul dibebaskan untuk menjualnya kepada bakul mana pun namun, dengan harga yang telah ditentukan oleh bakul tersebut. Sedangkan untuk bakul yang tidak memiliki hutang kepada bos atau agen besar bebas menjual kepada bos mana pun dengan harga yang ditentukan oleh bakul tersebut. Bakul baru akan menjual hasil produksinya kepada bos atau agen besar yang berani membeli dengan harga yang mahal.

Contoh dari bakul yang memulai usahanya dari level kecil adalah ibu Iyem yang mengaku bahwa ia menjadi bakul yang berlevel sama dengan yang lainnya setelah mendapatkan suntikan modal dari bos besar yang ia sebutkan dengan nama Haji Persis. Sehingga ia harus memberikan hasil pengumpulan dan barang produksinya kepada Haji Persis dan mendapatkan harga yang sesuai dengan yang telah ditentukan oleh Haji Persis, walaupun ia mengaku bahwa harga yang ia terima relatif lebih besar namun harga tersebut enggan ia sebutkan. Sehingga transparansi harga dari bakul kepada nelayan tidak pernah terjadi. Hal yang bertolak belakang adalah yang dilakukan oleh seorang bakul yang bernama ibu Uminah. Beliau memulai usaha dengan modal sendiri sehingga beliau bebas menjaul hasil produksinya 
kepada siapa saja dan dengan harga yang ditentukannya sendiri sehingga ia dapat memperoleh pendapatan yang lebih besar.

Sistem yang demikian tidak seimbang dengan keadaan yang dirasakan oleh nelayan. Pasalnya nelayan adalah produsen utama yang mengeluarkan segala resiko dan pembiayaan serta yang paling mengetahui bagaimana cara dan susahnya mencari tangakapan laut yang diinginkan. Namun relasi harga yang didapatkan oleh nelayan lagi-lagi hanya dapat ditentukan sendiri oleh bakul walaupun, nelayan tersebut tidak memiliki persangkutan hutang dengan bakul. Hal demikian merupakan relasi yang tidak adil bagi para nelayan. "jika dipikir secara logika, nelayan kan yang mengetahui bagaimana susahnya mencari rajungan tapi nelayan tidak bisa menentukan harga rajungan neng, saya juga ga ngerti neng kenapa bisa seperti itu. Yah begitulah orang Indonesia". Sehingga lagi-lagi nelayan harus menambah kredit hutangnya kepada para bakul. Hal demikian dilakukan karena kondisi tangkapan yang tidak sesuai dengan kebutuhan nelayan dalam artian nelayan selalu mengalami pailit tangkapan yang mengharuskan mereka menambah kredit hutang mereka kepada para bakul dan dengan pembayaran yang belum jelas kapan nelayan dapat membayar seluruh hutang-hutangnya kepada bakul tersebut. Walaupun ada itikad suka sama suka antara bakul dengan nelayan, namun itikad baik bakul tersebut bukanlah solusi bagi keadaan nelayan. Justru memperparah keadaan nelayan.

Dengan keadaan yang serba terjepit, nelayan tetap berusaha menjalani roda perekonomian demi menjalankan hidup, sekalipun jalan untuk mendapatkan penghasilan pernah dilakukan, namun hal tersebut berujung pada keputusasaan, pasalnya usaha yang dilakuakn demi meningkatkan pendapatan adalah dengan acara menjualnya langsung kepada pabrik atau PT yang nantinya akan memproduksi dan mendistribusikan rajungan hingga ke luar negeri. Pada mulanya langkah ini memang berhasil, namun hanya berjalan dalam waktu yang singkat nelayan sudah mendapatkan pemupusan harapan yang dilakukan oleh bakul. bakul memutuskan hubungan anatara nelayan dengan pabrik atau PT tersebut dengan jalan melakukan negosisasi baik dengan pihak keamanan dan pihak pabrik untuk menghalau nelayan yang menjual hasil tangkapan langsung kepada oknum yang berada di dalam pabrik. Sehingga pada akhirnya nelayan mendapatkan jalan buntu atas jawaban dari ketidakberdayaan mereka. Dari pemutusan hubungan yang dilakukan oleh bakul tersebut mengakibatkan nelayan tidak dapat lagi langsung memasukkan hasil tangkapan mereka kepada pabrik atau PT tersebut sehingga lagi-lagi nelayan hanya bisa pasrah dan kembali kepada bakul atau tengkulak. 
Kekusaan tengkulak atau bakul yang tidak terbatas ini merupakan sumber dari ketidak berdayaan nelayan untuk mengelola hasil tangkapan mereka dan memproduksi hasil tangkapan mereka. Dengan alasan terjerat hutang, maka nelayan diharuskan memberikan hasil tangkapan mereka kepada bakul yang bersangkutan hingga hutang mereka dapat terlunasi. Sedangkan fakta yang ada berbanding terbalik dengan persyaratan yang begitu berat bagi nelayan. Pasalnya hutang nelayan terhadap bakul sudah mencapai pada level puluhan juta.

\section{G. Ekologi Politik dalam Ranah Politik Desa}

Desa Citemu sama seperti desa lain pada umumnya, memiliki pemerintahan dan wilayah kekuasaan, memiliki lembaga dan kelembagaan serta sistem pemerintahan yang dipimpin oleh kepala desa pada umumnya. Struktur pemerintahan pada desa Citemu juga masih relatif sama seperti layaknya desa pada umumnya. Hanya saja sistem demokrasi yang dianut oleh masyarakat desa Citemu sedikit berbeda dengan pesta demokrasi pada umumnya. Masyarakat desa Citemu tidak maerasa antusias untuk memeriahkan pesta demokrasi pemilihan kepala desanya sehingga pemilihan tersebut hanya sebatas formalitas. Dalam struktur lembaga dan kelembagaan desa Citemu memang relatif sama dengan desa pada umumnya, namun perbedaan sistem yang dijalankan oleh pemerintahan desa Citemu dengan desa lainnya jauh berbeda. Seperti proses pengambilan kebijakan yang tidak selalu berpihak kepada masyarakat. Pada sistem pengambilan kebijakannya, pemerintah desa Citemu tidak melibatkan masyarakat untuk turut andil menyumbangkan aspirasinya dalam menentukan kebijakan untuk kemaslahatan bersama. Hal ini tercermin dari berbagai kebijakan yang tidak dapat dirasakan adil oleh masyarakat. Bantuan pemerintah terhadap masyarakat nelayan yang digunakan untuk kepentingan nelayan menjadi tidak berarti dan tidak bermanfaat bagi kepentingan masyarakat. Pasalnya, realisasi program bantuan yang diluncurkan oleh pemerintah untuk kelompok nelayan tidak berjalan pada koridor yang sesungguhnya yang menyentuh pada kepentingan dan kebutuhan masyarakat.

Kesalahan realisasi terhadap dana bantuan ini merupakan bukti di mana lapisan masyarakat bawah tidak mau merangkul dan dirangkul dalam penentuan kebijakan untuk kepentingan bersama. Bagunan Tempat Pelelangan Ikan (TPI) merupakan salah satu bentuk realisasi bantuan pemerintah yang sama sekali tidak memberikan imbas yang baik bagi masyarakat nelayan. Sementara itu keberadaan PLTU yang juga turut andil dalam menambah deretan kesulitan nelayan juga tidak 
dapat memberikan dampak yang signifikan terhadap kesejahteraan masyarakat. Pasalnya pemerintah setempat sebagai penyambung lidah masyarakat dengan PLTU tidak mampu memberikan solusi yang terbaik untuk kepentingan kesejahteraan hidup masyarakat nelayan sehingga bantuan yang diberikan oleh PLTU hanya sebatas pada pembangunan gedung sekolah, beasiswa, air bersih, kesehatan yang sama sekali tidak menyentuh pada sisi profesi masyarakat sebagai nelayan.

Dalam struktur pemerintahan desa pada umumnya, pemerintahan desa diberikan dana oleh pemerintah pusat berupa APBD untuk kesejahteraan desa. Dana ini merupakan anggaran yang diberikan oleh pemerintah untuk kesejahteraan desa. Namun pada kenyataannya jumlah dana tersebut tidak pernah terlihat adanya bahkan sampai pada tingkat realisasi untuk kesejahteraan masyarakatpun tidak terlihat keberadaannya. Masyarakat desa Citemu tidak pernah mengetahui berapa jumlah bantuan yang diberikan oleh pihak pemerintah pusat maupun oleh pihak perusahaan dan PLTU untuk kesejahteraan masyarakat sehingga mereka terkesan acuh terhadap pemerintahan yang ada. Sehingga dana tersebut tidak pernah menyentuh pada sisi kepentingan masyarakat yang mendasar. Realisasi atas bantuan dana yang didapatkan hanya tertuang pada sisi di mana terdapat tokoh pemangku kepentingan yang berpengaruh dalam bidangnya seperti pembangunan gedung, pengajian untuk anak-anak yang dikoordinir oleh pemangku kepentingan tersebut sehingga masyarakat tidak dapat menuangkan aspirasinya.

Dalam sistem pemerintahan terdapat lembaga khusus yang berfungsi untuk mengawasi segala kinerja aparat pemerintah setempat, lembaga tersebut bernama BPD. Namun pada hakikatnya BPD di desa Citemu tidak terlalu menunjukkan kinerjanya sebagai lembaga pengawas pemerintahan setempat. Sehingga tidak ada perubahan terhadap sistem pemerintahan desa Citemu. Padahal pada hakikatnya BPD berfungsi untuk mengontrol setiap kebijakan yang dibuat oleh pemerintah setempat. Selain dari pada lembaga pengontol yang tidak stabil kesadaran kolektif masyarakat akan keadaan demikian terlalu rendah sehingga mereka acuh terhadap kondisi mereka sendiri.

\section{H. Kebijakan Ekologis}

Dalam rangka mengatasi persoalan kemiskinan dan kesejahteraan hidup nelayan, telah banyak program dan kebijakan yang telah gulirkan pemerintah. Program yang bersifat umum antara lain Program Inpres Desa Tertinggal (IDT), Program Keluarga Sejahtera, Program Pembangunan Prasarana Pendukung Desa 
Tertinggal (P3DT), Program Pengembangan Kecamatan (PPK), dan Program Jaring Pengaman Sosial (JPS). Sedangkan program yang secara khusus ditujukan untuk kelompok sasaran masyarakat nelayan antara lain program Pemberdayaan Masyarakat Pesisir (PEMP) dan Program Pengembangan Usaha Perikanan Tangkap Skala Kecil (PUPTSK).

Diantara program pemerintah yang hingga kini masih bergulir di desa Citemu adalah Program Pengembangan Desa Pesisir Tangguh (PDPT). Program ini merupakan prgram yang digulirkan oleh Kementerian Kelautan dan Perikanan melalui Direktorat Jenderal Kelautan, Pesisir dan Pulau-pulau Kecil. Secara umum, program ini bertujuan untuk menata dan meningkatkan kehidupan desa pesisir/nelayan berbasis masyarakat dan memfasilitasi peran dan fungsi masyarakat sebagai agen pembangunan kelautan dan perikanan. Prgram ini merupakan bagian pelaksanaan program PNPM MandiriKP melalui bantuan pengembangan manusia, sumber daya, infrastruktur/lingkungan, usaha dan siaga bencana dan perubahan iklim.

Dalam praktiknya, model pengembangan PDPT terdiri atas tiga bagian, yaitu : pertama, rencana pengembangan desa pesisir; kedua, penguatan kapasitas kelembagaan; dan ketiga, pencapaian kegiatan sebagai tujuan PDPT. Dengan model ini, muara dari program PDPT adalah terjadinya pengentasan kemiskinan, keberlanjutan kelembagaan masyarakat, kelestarian lingkungan, kemandirian keuangan desa dan kesiapsiagaan terhadap bencana dan perubahan iklim. Untuk mewujudkan ketaggguhan desa diperlukan kebijakan berupa fokus pengembangan kegiatan yang berorientasi pada penyelesaian persoalan-persoalan pokok yang dihadapi masyarakat desa pesisir. Adapun fokus pengembangan kegiatan yang dimaksud adalah : (1) Bina Manusia; (2) Bina Usaha; (3) Bina Sumber Daya; (4) Bina Lingkungan atau Infrastruktur; (5) Bina Siaga Bencana atau Perubahan Iklim.

Dari sekian banyak program-program tersebut, dalam kenyataannya, secara umum tidak membuat nasib nelayan menjadi lebih baik daripada sebelumnya. Salah satu penyebab kurang berhasilnya program-program pemerintah dalam menanggulangi kemiskinan nelayan adalah formulasi kebijakan yang bersifat top down. Formula yang diberikan cenderung seragam padahal masalah yang dihadapi nelayan sangat beragam dan seringkali sangat spesifik lokal. Di samping itu, upaya penanggulangan kemiskinan nelayan seringkali sangat bersifat teknis perikanan, yakni bagaimana upaya meningkatkan produksi hasil tangkapan, sementara kemiskinan harus 
dipandang secara holistik karena permasalahan yang dihadapi sesungguhnya jauh lebih kompleks dari itu.

Pada konteks masyarakat Citemu, program-program tersebut, terutama prgram PDPT, tidak ber[engaruh dan berdampak secara signifikan terhadap kesejahteraan hidup nelayan. Hal ini terutama disebabkan karena dalam pelaksanaannya, nelayan kecil atau nelayan buruh sebagai kelompok mayoritas tidak ditempatkan sebagai kelompok sasaran (target group) utama. Hal ini misalnya bisa dilihat dari implementasi program yang lebih mengutamakan pembangunan sarana dan sarana fisik ketimbang pemenuhan kebutuhan mereka. Disamping itu, program itu dilaksanakan oleh para pelaksana yang sesungguhnya tidak mengerti kebutuhan nelayan sehingga pelaksanaannya tidak berhubungan langsung dengan kebutuhan nelayan dan perangkat-perangkat sosial mereka. Sehingga nelayan merasa asing dan merasa apatis dengan program itu.

Persoalan terkait kebijakan juga terlihat pada saat pelaksanaan proyek pembangunan Pembangkit Listrik Tenaga Uap (PLTU) di Citemu. Keberdaan pryek ini tentu saja, semakin memperpuruk nasib nelayan Citemu. Dengan adanya bangunan PLTU yang membentang hingga ke tengah laut bagian Timur membuat nelayan harus menambah jatah solar mereka untuk berlayar hingga ke laut bagian Timur, karena mereka harus memutari jembatan yang dibuat oleh PLTU yang membentang hingga tengah lautan. Pada dasarnya yang dirasakan nelayan adalah resiko bertambah penghasilan berkurang. Meskipun ada pertanggungjawaban dari PLTU yang memberikan sedikit bantuan untuk nelayan, namun bantuan tersebut tidak pernah menyentuh pada sisi profesi nelayan. karena PLTU hanya memberikan bantuan kepada nelayan pada sektor darat diantaranya bantuan sembako, kesehatan, pembangunan bak sampah, beasiswa, dan bangunan sekolah. Hal yang berkaitan dengan nelayan hanya pada alat bantu berupa alat penarik perahu yang digunakan nelayan untuk membawa perahunya sampai pada tepi sungai yang terletak di perbatasan desa Citemu dengan desa Bandengan. Meskipun mulanya PLTU menjanjikan program bantuan 2 liter solar untuk nelayan perhari. Namun pada tingkat realisasi program tersebut menemukan jalan buntu. Nelayan tidak pernah mendapatkan bantuan berupa solar dari PLTU.

Sementara untuk melakukan pemberdayaan masyarakat PLTU sebagai perusahaan juga turut andil dalam melakukan pengembangan dan pemberdayaan masyarakat. Pasalanya PLTU juga turut menyumbangkan faktor daftar kesulitan bagi nelayan untuk mendapatkan tangkapan mereka di laut. Bukan hanya pada jarak yang 
harus ditempuh, isu pencemaran lingkungan akibat limbah yang dihasilkan PLTU juga turut andil dalam permasalahan nelayan. sehingga peran PLTU bagi kehidupan nelayan sangat dibutuhkan. Dalam bidang pemberdayaan masyarakat peran PLTU diharapkan dapat meningkatkan ketahanan perekonomian nelayan, dengan memberikan solusi terbaik bagi nelayan untuk turut menyemarakkan pengembangan perekonomian nelayan. bukan malah menjejali nelayan dengan angan-angan kosong yang akhirnya menjadikan nelayan terlena dengan berbagai bantuan yang bersifat instan. Segala bentuk bantuan yang telah dilancarkan oleh PLTU sebagai bentuk pertanggungjawaban terhadap nelayan termasuk penyediaan air bersih menjadikan kepribadian dan mental mandiri nelayan terkikis, mereka menjadi asik dengan bantuan yang instan tersebut, sehingga pada akhirnya mereka bergantung pada segala jenis bantuan termasuk terbuka pada masyarakat luar yang datang. Dengan tidak memiliki ketahanan mental yang kuat bagi kepribadian mereka.

"kami sebagai penyambung lidah antara masyarakat desa Citemu dengan PLTU sudah berusaha memberikan yang terbaik untuk masyarakat". Perangkat desa menamakan dirinya sebagai penyambung lidah antara PLTU dengan masyarakat. Dalam kasus pertanggungjawaban PLTU dalam kesejahteraan masyarakat yang terkena dampak limbah PLTU secara langsung. Masyarakat desa Citemu adalah bagian dari korban yang paling merasakan dampak keberadaan PLTU di lingkungan kehidupannya. Baik dari segi kesehatan terutama dalam bidang perekonomian. Dahulu, desa Citemu merupakan salah satu daerah penghasil kerang ijo. Sebelum PLTU berdiri di tengah-tengah kehidupan nelayan. sebagain nelayan yang memiliki modal mengembangkan usaha mereka dalam bidang peternakan kerang ijo. Sebagai usaha alternatif kerang ijo termasuk salah satu usaha alternatif yang menjanjikan dapat memenuhi kebutuhan nelayan dalam bidang perekonomian, dengan hasil yang berlimpah dan kualitas bagus. Sehingga tingkat kesejahteraan masyarakat bukan hanya bertumpu pada aktivitas berlayar ke laut. Kerang ijo merupakan alternatif utama ketika tangkapan nelayan dari laut semakin sedikit. Namun seiring dengan berdirinya PLTU usaha pembudidayaan kerang ijo tidak lagi ditemukan di desa Citemu, pasalnya limbah PLTU merusak ekosistem kerang ijo sehingga tidak dapat berkembang dengan baik dan bahkan berujung pada kegagalan panen. Sementara untuk pengganti kerugian yang diderita oleh nelayan yang mengembangkan usaha dalam bidang pembudidayaan kerang ijo hanya diberikan sejumlah uang sebagai bentuk ganti rugi. Pemberian ganti rugi berupa uang tidak dapat memberikan manfaat apapun bagi 
kehidupan nelayan. dengan terhapusnya mata pencaharian mereka dalam bidang pengembangbiakkan kerang ijo nelayan kembali lagi menekuni usaha utama mereka yakni berlayar ke laut dan mengais rizki dari laut. Sementara bantuan uang tak dapat memberikan manfaat yang berkepanjangan dan hanya memberikan manfaat dalam jangka yang pendek, sementara itu usaha pengembangbiakkan kerang ijo sudah terhapuskan. Hal ini merupakan salah satu pemutusan roda perekonomian nelayan. sehingga pemerintah sebagai penyambung lidah antara masyarakat dengan PLTU tidak dapat memberikan suara yang terbaik untuk masyarakat desa yang berujung pada pemberian bantuan yang bermanfaat pada skala yang panjang.

Pemberian bantuan PLTU dalam bidang kesehatan, beasiswa, air bersih, gedung pendidikan, pembangunan tempat sampah dan sembako dianggap sebagai langkah yang kooperatif oleh pihak desa. Hal demikian tentu tidak dapat mendukung masyarakat desa Citemu menjadi lebih mandiri untuk mengembangkan kualitas hidup baik dibidang budaya maupun ekonomi. Sehingga pada akhirnya bantuan tersebut memberikan dampak pada pemberian wajah baru bagi masyarakat desa Citemu yang kehilangan kemandirian dan kepercayaan diri untuk bergerak dalam usaha dan karya yang mandiri. Sehingga masyarakat desa Citemu menjadi masyarakat yang terbuka pada masyarakat luar yang datang dan mengharapkan bantuan dari luar yang datang kepada mereka. Sebagai pemangku pemerintahan di desa Citemu, pemerintah desa maupun perangkatnya yang duduk dan menetap menjadi bagian dari masyarakat setidaknya mengetahui perbagai problematika masyarakat, sehigga pada dasarnya pemerintah mengetahui berbagai problem yang dihadapi masyarakat, namun nampaknya proses penyambungan lidah masyarakat ini masih diliputi oleh kebijakan yang bersifat memihak pada satu kepentingan. Sehingga kepentingan yang bersifat krusial dipandang sebelah mata dan dikesampingkan. Sementara itu anggapan pemerintah yang menayatakan bahwa "yang penting aman dan kondusif". Adalah sebuah moto yang sangat ciut dalam kalangan pemerintahan. Pasalnya masyarakatnya diharuskan menerima segala kondisi yang ada tanpa harus memberontak untuk menyuarakan hak mereka yang sudah terampas. Sehingga langkah demonstrasi terhadap kebijakan bantuan yang diberikan oleh PLTU dianggap sebagai tidakan yang anarkis yang dapat menhilangkan citra desa Citemu yang cinta damai.

\section{Kesimpulan}

Secara umum, sebagaimana lazimnya masyarakat pesisir, kemiskinan masyarakat nelayan Citemu disebabkan oleh tidak 
terpenuhinya hak-hak dasar mereka, antara lain kebutuhan akan pangan, kesehatan, pendidikan, pekerjaan, infrastruktur. Di samping itu, kurangnya kesempatan berusaha, kurangnya akses terhadap informasi, teknologi dan permodalan, budaya dan gaya hidup yang cenderung boros, menyebabkan posisi tawar mereka miskin semakin lemah. Di samping itu, sebab lain yang berpengaruh cukup signifikan atas kemiskinan mereka adalah karena meraka hidup dalam suasana alam yang keras yang selalu diliputi ketidakpastian (uncertainty) dalam menjalankan usahanya. Musim paceklik yang selalu datang tiap tahunnya dan lamanya pun tidak dapat dipastikan akan semakin membuat masyarakat nelayan terus berada dalam lingkaran setan kemiskinan (vicious circle) setiap tahunnya.

Dalam kegiatan ekonomi perikanan di desa Citemu, nelayan buruh atau bidak merupakan salah satu komponen sosial yang terpenting. Disamping pemilik perahu atau juragan, bidak merupakan pihak yang paling bertanggungjawab dalam organisasi penangkapan. Hubungan antara juragan dan bidak diikat oleh norma-norma kerjasama. Sebenarnya, dalam konteks sosial ekonomi masyarakat Citemu, hubungan antara bidak dan juragan ini tidak ada masalah yang berarti karena mereka lah ujung tombak kegiatan nelayan. Permasalahan muncul antara merak dengan para tengkulak atau para bakul. Hubungan antara bidak-juragan dengan bakul dibingkai dalam pola patron-klien.

Patron diperankan oleh para bakul dengan kepentingan untuk mendapatkan hasil tangkapan nelayan dengan harga murah dan memberikan kredit atau pinjaman dengan bunga tinggi. "Biasanya patron memberikan bantuan berupa modal kepada klien. Hal tersebut merupakan taktik bagi patron untuk mengikat klien dengan utangnya sehingga bisnis tetap berjalan" (Satria, 2002). Sedangkan klien diperankan oleh juragan-bidak dengan kepentingan untuk mendapatkan jaminan sosial ekonomi, berupa pinjaman uang disaat situasi sulit, bantuan barang-barang atau keperluan alat tangkap. Hubungan patron-klien ini dinilai kurang baik karena derajat keuntungannya diantara keduanya cukup berbeda, yakni patron lebih banyak memetik keuntungan dibandingkan klien. Tata hubungan patron-klien umumnya berkaitan dengan : pertama, hubungan diantara pelaku yang menguasai sumber daya tidak sama; kedua, hubungan yang bersifat khusus yang merupakan hubungan pribadi yang mengandung keakraban; dan ketiga, hubungan yang didasarkan atas asas saling menguntungkan. Mekanisme hubungan tersebut seringkali bersifat eksploitatif, dan sengaja dipelihara oleh patron. Diantara sifat ekspoitatif tersebut adalah keharusan klien untuk menjual hasil laut 
kepada patron dengan harga yang ditentukan oleh patron yang bahkan terkadang jauh di bawah harga pasar. Dengan pola hubungan ini, rasanya sulit sekali untuk meningkatkan kesejahteraan nelayan kecil di Citemu.

\section{J. Rekomendasi}

Secara umum, rekomendasi yang dapat disampaikan sebagai upaya penaggulangan masalah sosial yang dihadapi masyarakat nelayan adalah:

- Peningkatan kualitas pendidikan masyarakat nelayan. Dalam hal ini konteksnya adalah nelayan sebagai kepala rumah tangga, dan nelayan sebagai seperangkat keluarga. Nelayan yang buta huruf minimal bisa membaca atau lulus dalam paket A atau B. Anak nelayan diharapkan mampu menyelesaikan pendidikan tingkat menengah. Sehingga kedepan akses perkembangan tekhnologi kebaharian, peningkatan ekonomi lebih mudah dilakukan.

- Perlunya merubah pola kehidupan nelayan. Hal ini terkait dengan pola pikir dan kebiasaan. Pola hidup konsumtif harus dirubah agar nelayan tidak terpuruk ekonominya saat paceklik. Selain itu membiasakan budaya menabung supaya tidak terjerat rentenir. Selain itu perlu membangun diverifikasi mata pekerjaan khusus dipersiapkan menghadapi masa paceklik, seperti pengolahan ikan menjadi makanan, pengelolaan wialyah pantai dengan pariwisata dan bentuk penguatan ekonomi lain, sehingga bisa meningkatkan harga jual ikan, selain hanya mengandalakan ikan mentah.

- Peningkatan kualitas perlengkapan nelayan dan fasilitas pemasaran. Perlunya dukungan kelengkapan tekhnologi perahu maupun alat tangkap, agar kemampuan nelayan Indonesia bisa sepadan dengan nelayan bangsa lain. Begitupula fasilitas pengolahan dan penjualan ikan, sehingga harga jual ikan bisa ditingkatkan.

- Perlunya sebuah kebijakan sosial dari pemerintah yang berisikan program yang memihak nelayan, Kebijakan pemerintah terkait penanggulangan kemiskinan harus bersifat bottom up sesuai dengan kondisi, karakteristik dan kebutuhan masyarakat nelayan. Kebijakan yang lahir berdasarkan partisipasi atau keterlibatan masyarakat nelayan, bukan lagi menjadikan nelayan sebagai objek program, melainkan sebagai subjek. Selain itu penguatan dalam hal hukum terkait zona tangkap, penguatan armada patroli laut, dan pengaturan alat tangkap yang tidak mengeksploitasi kekayaan laut dan ramah lingkungan 


\section{DAFTAR PUSTAKA}

Adams, W., 1990, Green Development, London: Routledge.

Anwar C, Gunawan H. 2006, Peranan Ekologis dan Sosial Ekonomis Hutan Mangrove dalam Mendukung Pembangunan Wilayah Pesisir. Prosiding Hasil-hasil Penelitian: Konservasi dan Rehabilitasi Sumberdaya Hutan.

Bengen DG. 2004, Menuju Pembangunan Pesisir dan Laut Berkelanjutan berbasis Eko-Sosiosistem. Jakarta: Pusat Pembelajaran dan Pengembangan Pesisir dan Laut.

Bryant, L. Raymon, and Sinead Bailey, 2000, Third World Political Ecology, London and New York: Routledge.

Creswell, John W. 2003, Research Design, Quantative and Qualitative Approaches, London: Sage Publication.

Dahuri R, Rais J, Ginting SP, Sitepu MJ. 1996, Pengelolaan Sumber Daya Wilayah Pesisir dan Lautan secara Terpadu. Jakarta:

PT. Pradnya Paramitha.

Forsyth, T, 2003, Critical Political Ecology: The Politics of Environmental Science, London: Routledge.

Kusnadi, 2002, Konflik Sosial Nelayan: Kemiskinan dan Perebutan Sumber Daya Perikanan, Yogyakarta: LKiS. , 2008, Akar Kemiskinan Nelayan, Yogyakarta: LKiS. , 2007, Strategi Hidup Masyarakat Nelayan, Yogyakarta: LKiS.

Kusumastanto T., 2000, Sistem Sosial Ekonomi Budaya Masyarakat Pesisir. Makalah disampaikan dalam Diseminasi Pengelolaan Wilayah Pesisir dan Laut Jawa Barat, Bandung.

Marvasti, Amit B., 2004, Qualitative Research in Sociology, : SAGE Publications, Ltd.

Mulyadi, 2007, Ekonomi Kelautan, Jakarta: PT. Raja Grafindo Persada.

Neuman, W. Lawrence, 1991, Social Research Methods. Massachusetts: Allyn and Bacon.

Neumann, R.P., 2005, Making Political Ecology, London: Hodder Arnold.

Robbins, P., 2004, Political Ecology: A critical introduction, Malden, MA: Blackwell.

Rossman, Gretchen, B. and Sharon F. Rallis, 2003, Learning in the Field, London: SAGE Publications, Ltd.

Sastrawidjaja dan Manadiyanto, 2002, Nelayan Nusantara. Jakarta: Pusat Riset Pengolahan Produk dan Sosial Ekonomi Kelautan dan Perikanan. Badan Riset Kelautan dan Perikanan.

Satria, Arif, 2009, Ekologi Politik Nelayan, Yogyakarta: LKiS. 
Shaw, Ian and Nick Gould, 2001, Qualitative Social Work Research, London: SAGE Publications, Ltd.

Walker, P.A., 2005, Political ecology: Where is the ecology, Progress in Human Geography 29: 73-82.

Widodo, J. dan Suadi, 2008, Pengelolaan Sumberdaya Perikanan Laut, Yogyakarta: Gajah Mada University Press. 